\title{
Effect of intraoperative needle biopsy on the survival of nonsmall cell lung cancer patients: a propensity score matching analysis
}

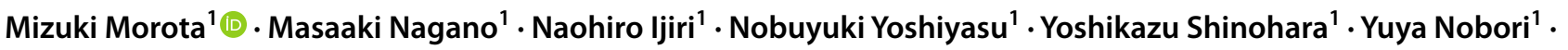 \\ Hirokazu Yamaguchi ${ }^{1}$. Shun Kawashima ${ }^{1}$. Masahiro Yanagiya ${ }^{1}$. Chihiro Konoeda ${ }^{1} \cdot$ Kentaro Kitano $^{1}$. \\ Masaaki Sato ${ }^{1} \cdot$ Jun Nakajima ${ }^{1}$
}

Received: 11 October 2021 / Accepted: 29 January 2022 / Published online: 3 March 2022

(c) The Author(s) 2022

\begin{abstract}
Purpose It is unknown whether intraoperative needle biopsy (INB) predisposes to the postoperative recurrence of lung cancer and compromises the prognosis of these patients. We conducted this study to identify the effect of INB before lobectomy on the postoperative recurrence rate and prognosis of patients with nonsmall cell lung cancer (NSCLC).

Methods The subjects of this retrospective study were 953 patients with pathological stage I-III NSCLC who underwent lobectomy between 2001 and 2016. The patients were divided into two groups: the INB group $(n=94)$ and the non-INB group $(n=859)$. After propensity score matching (PSM), we compared the postoperative cumulative recurrence rate, recurrencefree survival (RFS), disease-specific survival (DSS), and overall survival (OS) between the two groups.

Results After PSM, 94 patient pairs were matched. The cumulative recurrence rate was significantly higher in the INB group than in the non-INB group $(P=0.01)$. The 5-year RFS rate was significantly lower in the INB group than in non-INB group ( $48 \%$ vs $68 \%)$, as were the 5 -year DSS (76\% vs $92 \%)$ and 5-year OS rates $(67 \%$ vs $84 \%$ ) (all $P<0.05)$.

Conclusions The findings of this analysis suggest that INB before lobectomy may increase the cumulative recurrence rate and worsen the prognosis of patients with resectable NSCLC. Thus, we believe that INB should be avoided unless a lung lesion cannot be diagnosed by another type of biopsy.
\end{abstract}

Keywords Needle biopsy $\cdot$ Intraoperative biopsy $\cdot$ Lung cancer $\cdot$ Lobectomy $\cdot$ Survival

$\begin{array}{ll}\text { Abbreviations } & \\ \text { INB } & \text { Intraoperative needle biopsy } \\ \text { VATS } & \text { Video-assisted thoracoscopic } \\ & \text { surgery } \\ \text { CT } & \text { Computed TOMOGRAPHY } \\ \text { NSCLC } & \text { Non-small cell lung cancer } \\ \text { RFS } & \text { Recurrence-free survival } \\ \text { DSS } & \text { Disease-specific survival } \\ \text { OS } & \text { Overall survival } \\ \text { SMD } & \text { Standardized mean differences } \\ \text { PSM } & \text { Propensity score matching }\end{array}$

Mizuki Morota

morota-stm@umin.ac.jp

1 Department of Thoracic Surgery, Graduate School of Medicine, The University of Tokyo, 7-3-1, Hongo, Bunkyo-ku, Tokyo, Japan

\section{CTCs Circulating tumor cells \\ Meeting presentation Presented at the 38th Annual Meeting of the Japanese Associa- tion for Chest Surgery, Nagasaki, Japan, 20-21 May 2021.}

\section{Introduction}

Intraoperative needle biopsy (INB) is a common intraoperative diagnostic tool used in lung cancer surgery. INB is performed before lung resection to diagnose lung tumors that were not or could not be diagnosed preoperatively. The advantage of INB over other biopsy methods is that palpation and visual confirmation are used to directly identify the lung tumor. Even under complete video-assisted thoracoscopic surgery (VATS), the sensitivity, specificity, and accuracy of INB are $94.3 \%, 87.5 \%$, and $93.7 \%$, respectively [1]. INB can also reduce the waiting time until operation relative to preoperative biopsies, and costs less than partial 
lung resection biopsy [1-3]. Some reports on needle biopsy described pleural dissemination, whereas others examined the pleural dissemination rate of INB and computed tomography (CT)-guided needle biopsy for lung cancer [3-7]. However, the effect of INB on the postoperative recurrence of and prognosis for lung cancer remains unclear. The objective of our study was to identify the effect of INB before lobectomy on the postoperative recurrence rate (including distant metastasis) and prognosis associated with non-small cell lung cancer (NSCLC) by comparing the outcomes of patients who underwent INB and those who did not.

\section{Materials and methods}

This retrospective study was approved by the ethics committee of The University of Tokyo Hospital (Clinical Pilot Study No. 2406). We screened 1045 patients with pathological stage I-III NSCLC, who underwent lobectomy for curative resection (excluding pneumonectomy), with lymph node dissection, at the University of Tokyo Hospital between January, 2001 and December, 2016. Pathological staging of NSCLC was performed according to the seventh edition of The Union for International Cancer Control.

Patients who received neoadjuvant chemotherapy or radiotherapy, those with a history of lung cancer, those who had metachronous lung cancer during the observation period, those who died prior to hospital discharge, and those for whom no data were available, were excluded from the analysis $(n=92)$. Finally, 953 patients were the subjects of this retrospective study. The patients were divided into two groups: the INB group $(n=94)$ and the non-INB group $(n=859)$ (Fig. 1).

Clinical staging of NSCLC was based on the findings of $\mathrm{CT}$, brain magnetic resonance imaging, and positron emission tomography. Since 2016, endobronchial ultrasound-guided transbronchial needle aspiration has been performed for suspected clinical $\mathrm{N} 2$ disease. A tumor was defined as central if it involved the inner one-third of the hemithorax. Lobectomy was performed by thoracotomy or VATS. ND2a-1 was performed for $\mathrm{cN} 0$ disease and ND2a-2 was performed for $\mathrm{cN} 1$ or more severe disease. During VATS lobectomy, wounds were protected by trocars or protectors, and specimens were extracted using a bag. Lung cancer was diagnosed intraoperatively in all patients in the INB group. The surgical team selected either core needle biopsy $(16 \mathrm{G})$ or fine needle aspiration biopsy (18-19 G). The lung tumor was punctured several times and pressure hemostasis was applied just after the punctures. The area was washed before closing the wound. Generally, INB was performed when partial resection was made difficult by the location and size of the tumor and when the tumor was identified clearly intraoperatively and able to be punctured safely.

The non-INB group comprised patients who underwent lobectomy without biopsy, whose tumor could not be diagnosed by INB, but was diagnosed intraoperatively by partial lung resection, or preoperatively by transbronchial lung biopsy, CT-guided needle biopsy, or other methods.

The observation period was 5 years after surgery. Patients who were followed up at our hospital as outpatients underwent medical check-ups and chest X-rays or CT scans at least twice a year. The endpoints of this study were the postoperative cumulative recurrence rate, 5-year recurrence-free survival (RFS), 5-year disease-specific survival (DSS), and 5-year overall survival (OS).

\section{Statistical analysis}

Continuous variables are presented as medians and interquartile ranges, and nominal variables are presented as
Fig. 1 Overview of patient selection and grouping. NCSLC: non-small cell lung cancer; INB: intraoperative needle biopsy; PSM: propensity score matching

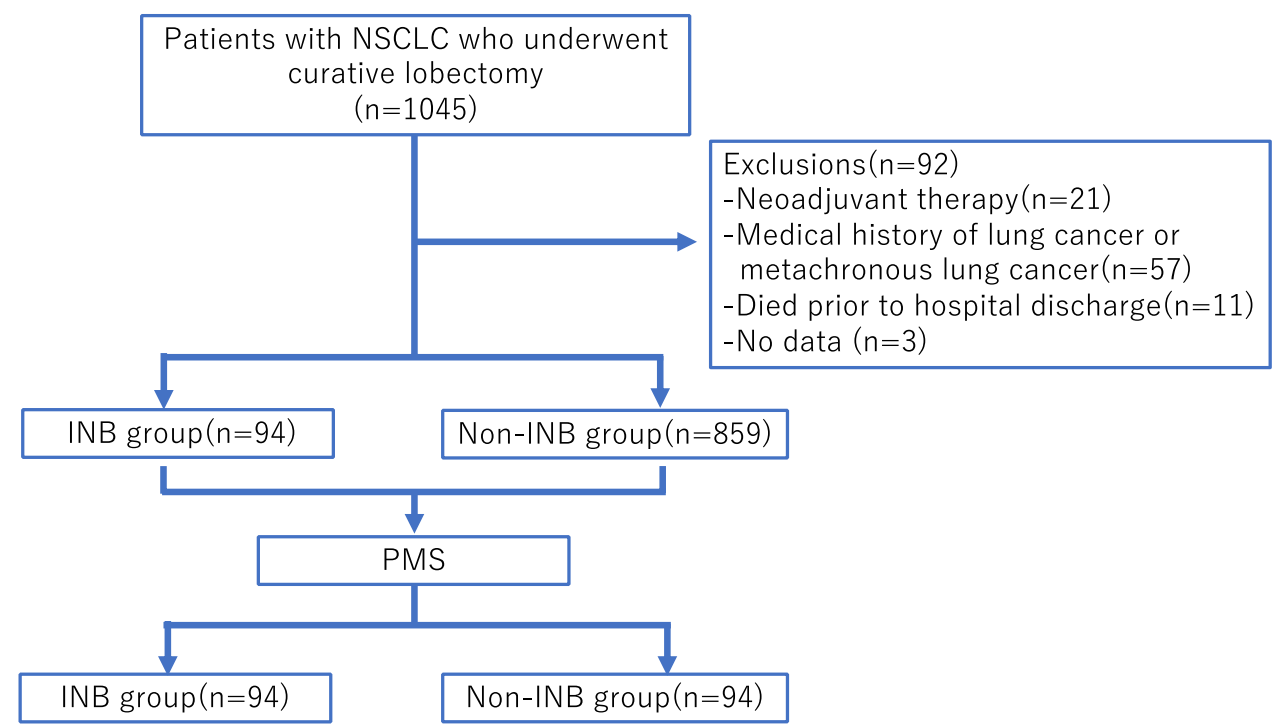


numbers and percentages. All statistical analyses were performed using EZR (Saitama Medical Center, Jichi Medical University, Saitama, Japan), a graphical user interface for R (The R Foundation for Statistical Computing, Vienna, Austria, version 3.6.1) [8]. Non-normally distributed continuous variables were compared by the Mann-Whitney $U$ test and categorical variables were compared by Pearson's chi-square test or Fisher's exact test. Gray's test was used to compare cumulative recurrence rates and the Kaplan-Meier method with the log-rank test was used to compare the RFS, DSS, and OS curves between the two groups. All $p$ values were two-sided, and $P<0.05$ was considered statistically significant. Propensity scores were calculated by logistic regression using 11 baseline characteristics (gender, age, histopathology, $p$-stage, tumor size, $\mathrm{pN}, \mathrm{v}, \mathrm{ly}, \mathrm{pl}, \mathrm{pm}$, adjuvant therapy). Patients were matched in a $1: 1$ ratio by the nearest neighbor method with the caliper value set at 0.2 . Standardized mean differences (SMD) are used to show the balance of matching.

\section{Results}

A total of 953 patients, divided into an INB group $(n=94)$ and a non-INB group $(n=859)$, were screened and analyzed retrospectively. Tables 1 and 2 summarize the patients' baseline characteristics. The median follow-up time was 60 (interquartile range, 41-60) months. Before propensity score matching (PSM), there were $42(44.7 \%)$ patients with recurrence in the INB group vs. $157(18.3 \%)$ in the non-INB group. The recurrence sites were the stump (4.3\%), pleura (9.6\%), lymph node $(10.6 \%)$, lung $(17 \%)$, brain $(9.6 \%)$, and bone $(3.2 \%)$ in the INB group and the stump $(0.7 \%)$, pleura (3.1\%), lymph node $(5.9 \%)$, lung $(5.4 \%)$, brain $(2.3 \%)$, bone $(2.3 \%)$, liver $(1.3 \%)$, and others $(0.6 \%)$ in the non-INB group, which included duplicates (Table 3). The cumulative recurrence rate was significantly higher in the INB group than in the non-INB group $(P<0.001)$. Five-year RFS was $48 \%$ in the INB group and $76 \%$ in the non-INB group, 5-year DSS was $76 \%$ in the INB group and $92 \%$ in the non-INB group, and 5-year OS was $67 \%$ in the INB group and $87 \%$ in the non-INB group. All of these differences were significant $(P<0.001)$. In the INB group, there were 29 patients who underwent core needle biopsy and 65 who underwent fine needle aspiration biopsy. The cumulative recurrence rate was not significantly different according to biopsy type $(P=0.85)$. The pleural recurrence rate was $5.3 \%$ for core needle biopsy and $4.3 \%$ for fine needle aspiration biopsy $(P=1.0)$.

After PSM, 94 pairs were matched between the INB group and the non-INB group. The two groups were well matched for 11 baseline characteristics. The cumulative recurrence rate was significantly higher in the INB group
Table 1 Baseline characteristics of the enrolled patients

\begin{tabular}{|c|c|}
\hline & Total $(n=953)$ \\
\hline \multicolumn{2}{|l|}{ Gender, $n(\%)$} \\
\hline Female & $373(39.1)$ \\
\hline Male & $580(60.9)$ \\
\hline Age & $69.0[62.0,75.0]$ \\
\hline \multicolumn{2}{|l|}{ Hisitopathology, $n(\%)$} \\
\hline Ad & 709 (74.4) \\
\hline $\mathrm{Sq}$ & $187(19.6)$ \\
\hline Others & $57(6.0)$ \\
\hline \multicolumn{2}{|l|}{ p-stage, $n(\%)$} \\
\hline IA & $431(45.2)$ \\
\hline IB & $248(26.0)$ \\
\hline II & $154(16.2)$ \\
\hline III & $120(12.6)$ \\
\hline Tumor size (mm) & $25.0[16.0,35.0]$ \\
\hline \multicolumn{2}{|l|}{$p N, n(\%)$} \\
\hline N0 & $761(79.9)$ \\
\hline N1-3 & $192(20.1)$ \\
\hline \multicolumn{2}{|l|}{$v, n(\%)$} \\
\hline Negative & $567(59.5)$ \\
\hline Positive & $386(40.5)$ \\
\hline \multicolumn{2}{|l|}{$l y, n(\%)$} \\
\hline Negative & $763(80.1)$ \\
\hline Positive & $190(19.9)$ \\
\hline \multicolumn{2}{|l|}{$p l, n(\%)$} \\
\hline Negative & $621(65.2)$ \\
\hline Positive & $332(34.8)$ \\
\hline \multicolumn{2}{|l|}{$p m, n(\%)$} \\
\hline Negative & $916(96.1)$ \\
\hline Positive & 37 ( 3.9$)$ \\
\hline \multicolumn{2}{|l|}{ Adjuvant therapy, $n(\%)$} \\
\hline- & 790 (82.9) \\
\hline+ & $163(17.1)$ \\
\hline \multicolumn{2}{|l|}{ Reccurence, $n(\%)$} \\
\hline- & $754(79.1)$ \\
\hline+ & 199 (20.9) \\
\hline Follow-up time (month) & $60.0[40.9,60.0]$ \\
\hline
\end{tabular}

Variables are presented as medians (interquartile range) unless otherwise indicated

Ad adenocarcinoma, $S q$ Squamous cell carcinoma, $p$-stage pathological stage, $p N$ pathological $\mathrm{N}$ category, $v$ vessel invasion, ly lymphatic invasion, $p l$ pleural invasion, $p m$ pulmonary metastasis in the primary lobe, $I N B$ intraoperative needle biopsy, $S M D$ standardized mean differences

than in the non-INB group $(P=0.01)$. The 5-year RFS was $48 \%$ in the INB group and $68 \%$ in the non-INB group, the 5-year DSS was $76 \%$ in the INB group and $92 \%$ in the non-INB group, and the 5-year OS was $67 \%$ in the INB group and $84 \%$ in the non-INB group. All these differences were significant $(P<0.05)$ (Figs. 2 and 3$)$. There 
Table 2 Baseline characteristics of the cohorts before and after propensity score matching

\begin{tabular}{|c|c|c|c|c|c|c|c|c|}
\hline & \multicolumn{4}{|l|}{ Before PSM } & \multicolumn{4}{|l|}{ After PSM } \\
\hline & $\begin{array}{l}\text { Non-INB group } \\
(n=859)\end{array}$ & INB group $(n=94)$ & $P$-value & SMD & $\begin{array}{l}\text { Non-INB group } \\
(n=94)\end{array}$ & INB group $(n=94)$ & $P$-value & SMD \\
\hline \multicolumn{9}{|l|}{ Gender, $n(\%)$} \\
\hline Female & $335(39.0)$ & $38(40.4)$ & 0.82 & 0.029 & $41(43.6)$ & $38(40.4)$ & 0.768 & 0.065 \\
\hline Male & $524(61.0)$ & $56(59.6)$ & & & $53(56.4)$ & $56(59.6)$ & & \\
\hline Age & $69.0[62.0,75.0]$ & $68.5[63.0,75.0]$ & 0.96 & 0.040 & $70.0[62.3,76.0]$ & $68.5[63.0,75.0]$ & 0.651 & 0.002 \\
\hline \multicolumn{9}{|l|}{$\begin{array}{l}\text { Hisitopathology, } n \\
\quad(\%)\end{array}$} \\
\hline Ad & $644(75.0)$ & $65(69.1)$ & 0.38 & 0.136 & $61(64.9)$ & $65(69.1)$ & 0.769 & 0.103 \\
\hline $\mathrm{Sq}$ & $164(19.1)$ & $23(24.5)$ & & & $25(26.6)$ & $23(24.5)$ & & \\
\hline Others & $51(5.9)$ & $6(6.4)$ & & & $8(8.5)$ & $6(6.4)$ & & \\
\hline \multicolumn{9}{|l|}{ p-stage, $n(\%)$} \\
\hline IA & $401(46.7)$ & 30 (31.9) & 0.034 & 0.317 & $28(29.8)$ & 30 (31.9) & 0.96 & 0.089 \\
\hline IB & $218(25.4)$ & $30(31.9)$ & & & $32(34.0)$ & $30(31.9)$ & & \\
\hline II & 137 (15.9) & $17(18.1)$ & & & $15(16.0)$ & $17(18.1)$ & & \\
\hline III & $103(12.0)$ & $17(18.1)$ & & & $19(20.2)$ & $17(18.1)$ & & \\
\hline Tumor size (mm) & $25.0[15.0,35.0]$ & $28.0[20.0,37.3]$ & 0.017 & 0.192 & $28.0[20.0,41.5]$ & $28.0[20.0,37.3]$ & 0.971 & 0.003 \\
\hline \multicolumn{9}{|l|}{$p N, n(\%)$} \\
\hline No & $690(80.3)$ & $71(75.5)$ & 0.28 & 0.116 & $68(72.3)$ & $71(75.5)$ & 0.74 & 0.073 \\
\hline N1-3 & 169 (19.7) & $23(24.5)$ & & & $26(27.7)$ & $23(24.5)$ & & \\
\hline \multicolumn{9}{|l|}{$v, n(\%)$} \\
\hline Negative & $518(60.3)$ & $49(52.1)$ & 0.15 & 0.165 & $48(51.1)$ & $49(52.1)$ & 1 & 0.021 \\
\hline Positive & 341 (39.7) & 45 (47.9) & & & $46(48.9)$ & $45(47.9)$ & & \\
\hline \multicolumn{9}{|l|}{$l y, n(\%)$} \\
\hline Negative & $695(80.9)$ & $68(72.3)$ & 0.057 & 0.203 & $66(70.2)$ & $68(72.3)$ & 0.872 & 0.047 \\
\hline Positive & $164(19.1)$ & $26(27.7)$ & & & $28(29.8)$ & $26(27.7)$ & & \\
\hline \multicolumn{9}{|l|}{$p l, n(\%)$} \\
\hline Negative & $572(66.6)$ & $49(52.1)$ & 0.006 & 0.298 & $55(58.5)$ & $49(52.1)$ & 0.463 & 0.129 \\
\hline Positive & $287(33.4)$ & $45(47.9)$ & & & $39(41.5)$ & $45(47.9)$ & & \\
\hline \multicolumn{9}{|l|}{$p m, n(\%)$} \\
\hline Negative & $827(96.3)$ & $89(94.7)$ & 0.4 & 0.077 & 87 (92.6) & $89(94.7)$ & 0.767 & 0.087 \\
\hline Positive & $32(3.7)$ & $5(5.3)$ & & & $7(7.4)$ & $5(5.3)$ & & \\
\hline \multicolumn{9}{|l|}{$\begin{array}{l}\text { Adjuvant therapy, } \\
n(\%)\end{array}$} \\
\hline- & 717 (83.5) & $73(77.7)$ & 0.15 & 0.147 & $72(76.6)$ & $73(77.7)$ & 1 & 0.025 \\
\hline+ & $142(16.5)$ & $21(22.3)$ & & & $22(23.4)$ & $21(22.3)$ & & \\
\hline \multicolumn{9}{|l|}{ Reccurence, $n(\%)$} \\
\hline- & 702 (81.7) & $52(55.3)$ & & & $71(75.5)$ & $52(55.3)$ & & \\
\hline+ & $157(18.3)$ & $42(44.7)$ & & & $23(24.5)$ & $42(44.7)$ & & \\
\hline $\begin{array}{l}\text { Follow-up time } \\
\text { (month) }\end{array}$ & $60.0[42.1,60.0]$ & $55.8[32.2,60.0]$ & & & $60.0[35.9,60.0]$ & $55.8[32.2,60.0]$ & & \\
\hline
\end{tabular}

Variables are presented as medians (interquartile range) unless otherwise indicated

$A d$ adenocarcinoma, $S q$ Squamous cell carcinoma, $p$-stage pathological stage, $p N$ pathological $\mathrm{N}$ category, $v$ vessel invasion, $l y$ lymphatic invasion, $p l$ pleural invasion, $p m$ pulmonary metastasis in the primary lobe, INB intraoperative needle biopsy, PSM propensity score matching, SMD standardized mean differences

were no significant differences in tumor location between the groups $(P=0.57): 16 \%$ of tumors were central in the INB group and $20 \%$ of tumors were central in the non-INB group.
Among patients with p-stage I disease, the cumulative recurrence rate was higher in the INB group than in the non-INB group before and after PSM $(P<0.01)$. The rate of pleural recurrence was higher in the INB group than in 
Table 3 Sites of recurrence in patients before and after propensity score matching

\begin{tabular}{|c|c|c|c|c|c|c|}
\hline & \multicolumn{3}{|l|}{ Before PSM } & \multicolumn{3}{|l|}{ After PSM } \\
\hline & $\begin{array}{l}\text { Non-INB } \\
\text { group }(n=859)\end{array}$ & $\begin{array}{l}\text { INB group } \\
(n=94)\end{array}$ & $P$-value & $\begin{array}{l}\text { Non-INB } \\
\text { group }(n=94)\end{array}$ & $\begin{array}{l}\text { INB group } \\
(n=94)\end{array}$ & $P$-value \\
\hline \multicolumn{7}{|c|}{ Recurrence site (\%) } \\
\hline Stump & 0.7 & 4.3 & 0.01 & 1.1 & 4.3 & 0.37 \\
\hline Pleura & 3.1 & 9.6 & $<0.01$ & 2.1 & 9.6 & 0.06 \\
\hline Lymph node & 5.9 & 10.6 & 0.12 & 7.4 & 10.6 & 0.61 \\
\hline Lung & 5.4 & 17.0 & $<0.01$ & 6.4 & 17.0 & 0.04 \\
\hline Brain & 2.3 & 9.6 & $<0.01$ & 5.3 & 9.6 & 0.41 \\
\hline Bone & 2.3 & 3.2 & 0.49 & 3.2 & 3.2 & 1.0 \\
\hline Liver & 1.3 & 0.0 & 0.61 & 1.1 & 0.0 & 1.0 \\
\hline Others & 0.6 & 0.0 & 1.0 & 1.1 & 0.0 & 1.0 \\
\hline
\end{tabular}

INB intraoperative needle biopsy, PSM propensity score matching, SMD standardized mean differences
A

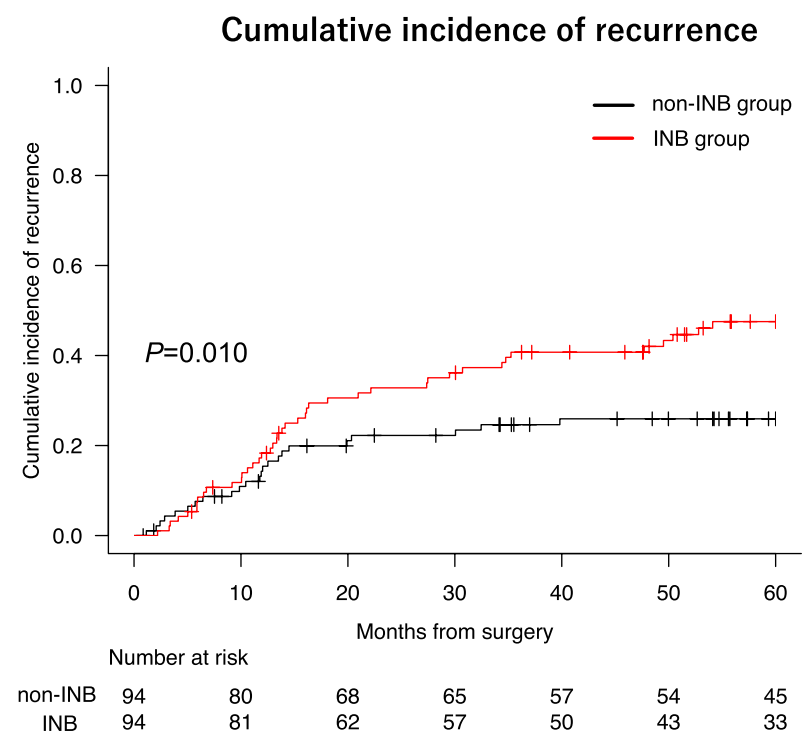

Fig. 2 A Gray's test for the cumulative recurrence rate in the intraoperative needle biopsy (INB) group vs. the non-INB group $(P=0.010)$. B Log-rank test for 5-year recurrence-free survival (RFS) after pro-

the non-INB group before and after PSM ( $4.3 \%$ vs. $1.6 \%$ and $4.3 \%$ vs. $0 \%$, respectively).

\section{Discussion}

Based on the findings of this study, INB increased the recurrence rate and decreased 5-year survival. Sawabata et al. reported that fine-needle aspiration biopsy causes mechanical exfoliation of tumor cells into the pleural cavity [6]. During INB, blood spreads into the thoracic cavity from the puncture, forming a hematoma around the punctured spot, suggesting that the puncture causes tumor cells to become liberated, spread out, and circulate. Accordingly, in the
B

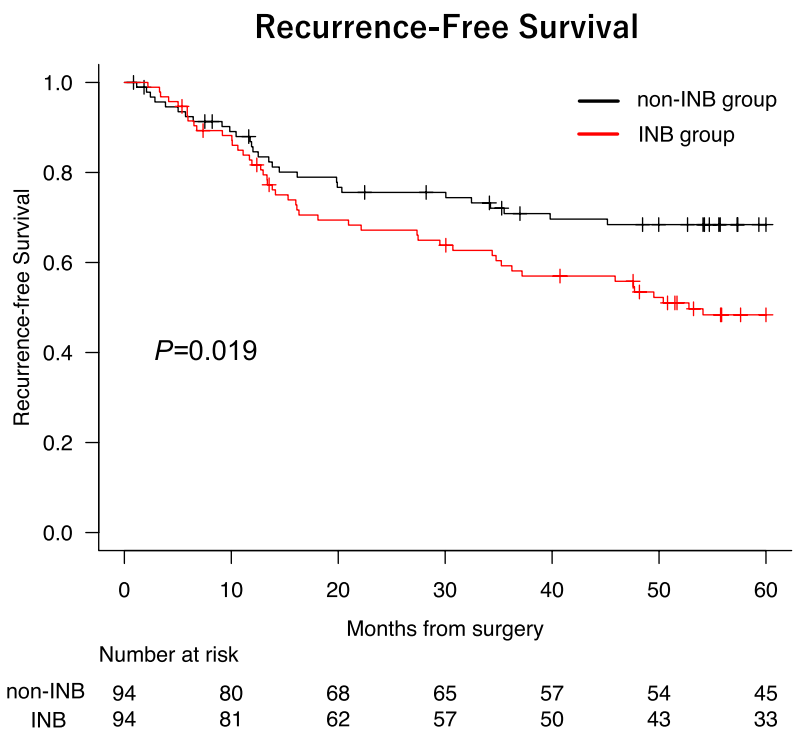

pensity score matching. The 5 -year RFS was $48 \%$ in the INB group and $68 \%$ in the non-INB group $(P=0.019)$

present study, the pleural recurrence rate was higher in the INB group than in the non-INB group.

A recent study found that surgical procedures and manipulation affect the level of circulating tumor cells (CTCs) and ultimately, the prognosis. CTCs become more abundant after surgical manipulation, and patients with cluster CTCs had significantly lower RFS and OS [9-14]. Wei et al. showed that the vein-first ligating technique was better than the artery-first technique for lobectomy, in terms of prognosis and reduction of CTCs, for patients with NSCLC [15]. Yasukawa et al. found that partial resection before lobectomy decreases the recurrence rate and improves RFS of patients with early-stage lung adenocarcinoma [16]. Partial resection was used to create a tumor-free environment before 
A

Disease-specific Survival

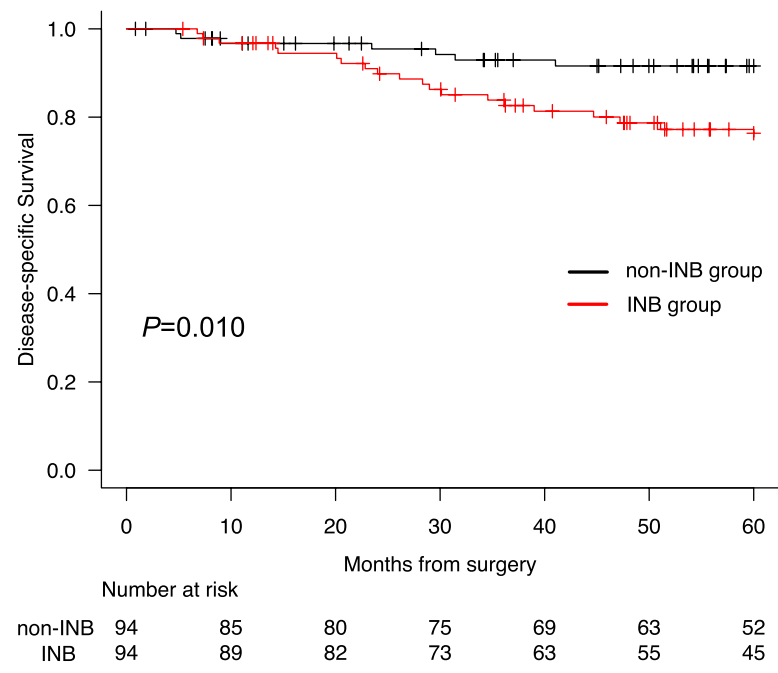

Fig. 3 A Log-rank test for 5-year disease-specific survival (DSS) in the INB group vs. the non-INB group. B The 5-year overall survival (OS) after propensity score matching. The 5-year DSS was $76 \%$ in

lobectomy. When performing INB, the tumor remains until lobectomy is initiated. Therefore, unless the drainage pulmonary vein is ligated, CTCs will remain high. In our study, the rates of recurrence in the lung and brain were significantly higher in the INB group than in the non-INB group, supporting this theory of previous studies. Based on the nature of the INB procedure, it is easy to interpret the findings of this study.

In comparing the preoperative and intraoperative biopsies, Taniguchi et al. reported that a preoperative biopsy did not worsen prognosis relative to a lung resection biopsy in patients with cTanyNOM0 NSCLC, as revealed by multivariate analysis [17]. Conversely, Nakajima et al. reported that the RFS of patients who underwent resection of earlystage NCSLC was better in their intraoperative biopsy group than in their transbronchial biopsy group [18]. Huang et al. reported that preoperative biopsy was an independent factor influencing overall recurrence and that it worsened the disease-free survival of patients with stage I adenocarcinoma, as determined by multivariate analysis adjusted by PSM [19]. As mentioned, Yasukawa et al. reported that intraoperative partial pulmonary resection before lobectomy decreased the recurrence rate and improved RFS of earlystage lung adenocarcinoma patients [16].

Based on these studies and our findings, intraoperative partial resection biopsy seems to be a better choice for diagnosing lung tumors. However, all these studies were retrospective and the relationship between biopsy and prognosis has not been investigated fully, so it is difficult to establish which biopsy procedure is most appropriate.
B

\section{Overall Survival}

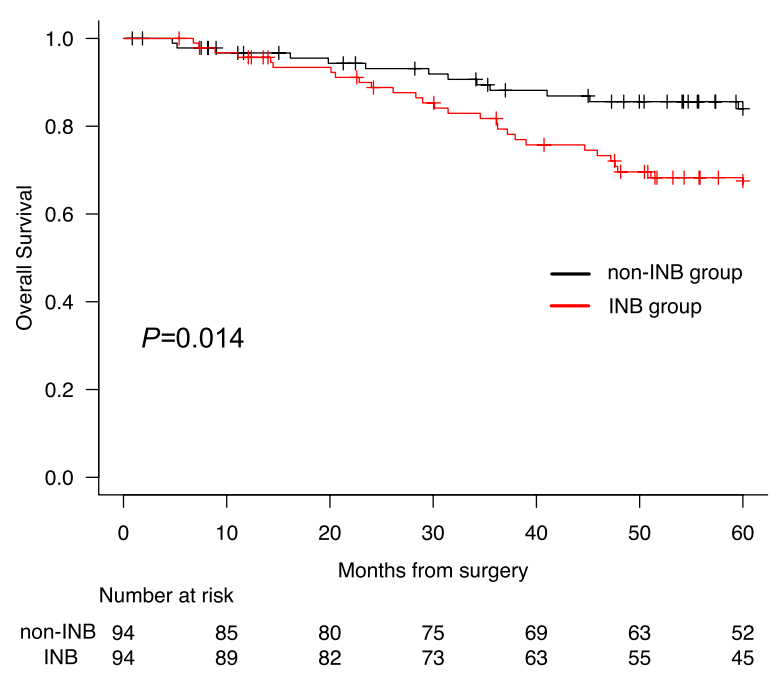

the INB group and $92 \%$ in the non-INB group $(P=0.010)$, and the 5 -year OS was $67 \%$ in the INB group and $84 \%$ in the non-INB group $(P=0.014)$

When performing biopsies other than INB has been difficult and malignancy is strongly suggested by preoperative examination, complete resection without biopsy remains an option. In 2018, the 30-day mortality rate of patients who underwent lobectomy for primary lung cancer in Japan was only $0.2 \%$ [20]. Furthermore, image diagnosis supported by artificial intelligence and deep learning is being studied to improve the accuracy of preoperative noninvasive diagnosis [21-23]. If the accuracy of preoperative, noninvasive diagnostic tools is upgraded and supported by sufficient evidence, curative resection without biopsy may become a standard procedure for resectable NSCLC. If this evolves, fewer patients will require INB, potentially changing the prognosis of resectable NSCLC.

\section{Limitations}

Our study has several limitations. First, it was a retrospective study in a single-institution setting. INB is commonly selected to diagnose peripheral solid tumors, so $\mathrm{pl}, \mathrm{ly}$, v, and other data were included as PSM characteristics to minimize selection bias, but this approximation is limited. Second, the sample size was small, with only 94 patient pairs included in the analysis. Third, we did not examine the subtype of adenocarcinoma, or the relationship between the INB procedure and CTCs. Prospective studies that examine the effect of each type of biopsy on patients with resectable NSCLC, or even retrospective studies with larger sample sizes or multicenter studies, are needed. 


\section{Conclusions}

Performing INB before lobectomy has the potential to increase the cumulative recurrence rate and worsen the prognosis of patients with resectable NSCLC. Based on our findings, INB should be limited to when the diagnosis of NSCLC cannot be confirmed using any other kind of biopsy.

\section{Acknowledgements None.}

\section{Declarations}

Conflict of interest Nobuyuki Yoshiyasu received a research grant from Daiwa Securities Health Foundation. None of the other authors have any conflicts of interest to declare.

Open Access This article is licensed under a Creative Commons Attribution 4.0 International License, which permits use, sharing, adaptation, distribution and reproduction in any medium or format, as long as you give appropriate credit to the original author(s) and the source, provide a link to the Creative Commons licence, and indicate if changes were made. The images or other third party material in this article are included in the article's Creative Commons licence, unless indicated otherwise in a credit line to the material. If material is not included in the article's Creative Commons licence and your intended use is not permitted by statutory regulation or exceeds the permitted use, you will need to obtain permission directly from the copyright holder. To view a copy of this licence, visit http://creativecommons.org/licenses/by/4.0/.

\section{References}

1. Isaka T, Takahashi K, Maehara T, Masuda M. Intraoperative core needle biopsy under complete video-assisted thoracic surgery for indeterminate tumor of lung. Surg Endosc. 2015;29:3579-87.

2. Nakajima J, Furuse A, Kohno T, Ohtsuka T, Matsumoto J, Oka T. Transthoracoscopic needle biopsy for indeterminate lung nodules. Surg Endosc. 1999;13:386-9.

3. Matsuoka T, Sonobe M, Date H. Intraoperative fine-needle aspiration biopsy (FNA) for lung cancer: diagnostic value and risk of pleural dissemination. Surg Today. 2015;45:695-9.

4. Toyoda T, Suzuki H, Hata A, Yamamoto T, Morimoto J, Sakairi $\mathrm{Y}$, et al. Is needle biopsy a risk factor of pleural recurrence after surgery for non-small cell lung cancer? J Thorac Dis AME Publishing Company. 2020;13:2635-43.

5. Inoue $\mathrm{M}$, Honda $\mathrm{O}$, Tomiyama $\mathrm{N}$, Minami M, Sawabata $\mathrm{N}$, Kadota $\mathrm{Y}$, et al. Risk of pleural recurrence after computed tomographicguided percutaneous needle biopsy in stage I lung cancer patients. Ann Thorac Surg. 2011;91:1066-71.

6. Sawabata N, Ohta M, Maeda H. Fine-needle aspiration cytologic technique for lung cancer has a high potential of malignant cell spread through the tract. Chest. 2000;118:936-9.

7. Matsuguma H, Nakahara R, Kondo T, Kamiyama Y, Mori $\mathrm{K}$, Yokoi K. Risk of pleural recurrence after needle biopsy in patients with resected early stage lung cancer. Ann Thorac Surg. 2005;80:2026-31.

8. Kanda Y. Investigation of the freely available easy-to-use software "EZR" for medical statistics. Bone Marrow Transplant. 2013;48:452-8.
9. Hashimoto M, Tanaka F, Yoneda K, Takuwa T, Matsumoto S, Okumura Y, et al. Significant increase in circulating tumour cells in pulmonary venous blood during surgical manipulation in patients with primary lung cancer. Interact Cardiovasc Thorac Surg. 2014;18:775-83.

10. Song PP, Zhang W, Zhang B, Liu Q, Du J. Effects of different sequences of pulmonary artery and vein ligations during pulmonary lobectomy on blood micrometastasis of non-small cell lung cancer. Oncol Lett. 2013;5:463-8.

11. Sawabata N, Susaki Y, Nakamura T, Kawaguchi T, Yasukawa M, Taniguchi S. Cluster circulating tumor cells in surgical cases of lung cancer. Gen Thorac Cardiovasc Surg. 2020;68:975-83.

12. Kurusu Y, Yamashita J, Hayashi N, Mita S, Fujino N, Ogawa $\mathrm{M}$. The sequence of vessel ligation affects tumor release into the circulation. J Thorac Cardiovasc Surg. 1998;116:107-13.

13. Matsutani N, Sawabata N, Yamaguchi M, Woo T, Kudo Y, Kawase A, et al. Does lung cancer surgery cause circulating tumor cells? A multicenter, prospective study. J Thorac Dis. 2017;9:2419.

14. Duan X, Zhu Y, Cui Y, Yang Z, Zhou S, Han Y, et al. Circulating tumor cells in the pulmonary vein increase significantly after lobectomy: A prospective observational study. Thorac Cancer. 2019;10:163-9.

15. Wei S, Guo C, He J, Tan Q, Mei J, Yang Z, et al. Effect of veinfirst vs artery-first surgical technique on circulating tumor cells and survival in patients with non-small cell lung cancer: a randomized clinical trial and registry-based propensity score matching analysis. JAMA Surg. 2019;154: e190972. https://doi.org/10. 1001/jamasurg.2019.0972.

16. Yasukawa M, Sawabata N, Kawaguchi T, Taniguchi S. Effectiveness of intraoperative pulmonary wedge resection of tumor site before lobectomy for early lung adenocarcinoma. Anticancer Res. 2019;39:6829-34.

17. Taniguchi Y, Fukumoto K, Matsui H, Saito T, Murakawa T. Preoperative biopsy does not affect postoperative outcomes of resectable non-small cell lung cancer. Gen Thorac Cardiovasc Surg. 2019;67:615-23.

18. Nakajima J, Takamoto S, Matsumoto J, Takeuchi E, Ito YM. Effect of preoperative transbronchial biopsy on prognosis of non-small cell lung cancer. Asian Cardiovasc Thorac Ann. 2004;12:330-5.

19. Huang CS, Hsu PK, Chen CK, Yeh YC, Chen HS, Wu MH, et al. Preoperative biopsy and tumor recurrence of stage I adenocarcinoma of the lung. Surg Today. 2020;50:673-84.

20. Shimizu H, Okada M, Toh Y, Doki Y, Endo S, Fukuda H, et al. Thoracic and cardiovascular surgeries in Japan during 2018. Gen Thorac Cardiovasc Surg. 2020;69:179-212.

21. Avanzo M, Stancanello J, Pirrone G, Sartor G. Radiomics and deep learning in lung cancer. Strahlenther Onkol. 2020;196:879-87.

22. Wong CW, Chaudhry A. Radiogenomics of lung cancer. J Thorac Dis. 2020;12:5104-9.

23. Ardila D, Kiraly AP, Bharadwaj S, Choi B, Reicher JJ, Peng L, et al. End-to-end lung cancer screening with three-dimensional deep learning on low-dose chest computed tomography. Nat Med. 2019;25:954-61.

Publisher's Note Springer Nature remains neutral with regard to jurisdictional claims in published maps and institutional affiliations. 